\title{
Author Correction: Van der Waals engineering of ferroelectric heterostructures for long-retention memory
}

\author{
Xiaowei Wang (1D, Chao Zhu (D), Ya Deng, Ruihuan Duan, Jieqiong Chen, Qingsheng Zeng, Jiadong Zhou (D),
} Qundong Fu, Lu You (D), Song Liu, James H. Edgar (D), Peng Yu \& Zheng Liu (D)

Correction to: Nature Communications https://doi.org/10.1038/s41467-021-21320-2, published online 17 February 2021.

The original version of this Article contained an error in the Acknowledgements:

NRF-CRP22-2019-0060 should have read NRF-CRP22-2019-0007.

This has now been corrected in both the PDF and HTML versions of the Article.

Published online: 10 May 2021

\begin{abstract}
(c) (i) Open Access This article is licensed under a Creative Commons Attribution 4.0 International License, which permits use, sharing, adaptation, distribution and reproduction in any medium or format, as long as you give appropriate credit to the original author(s) and the source, provide a link to the Creative Commons license, and indicate if changes were made. The images or other third party material in this article are included in the article's Creative Commons license, unless indicated otherwise in a credit line to the material. If material is not included in the article's Creative Commons license and your intended use is not permitted by statutory regulation or exceeds the permitted use, you will need to obtain permission directly from the copyright holder. To view a copy of this license, visit http://creativecommons.org/licenses/by/4.0/.
\end{abstract}

() The Author(s) 2021 